\title{
REVIEW
}

\section{Two forms of reactive arthritis?}

\author{
Paavo Toivanen, Auli Toivanen
}

\begin{abstract}
Inflammatory arthritides developing after a distant infection have so far been called reactive or postinfectious, quite often depending on the microbial trigger and/or HLA-B27 status of the patient. For clarity, it is proposed that they all should be called reactive arthritis, which, according to the trigger, occurs as an HLA-B27 associated or non-associated form. In addition to the causative agents and HLA-B27, these two categories are also distinguished by other characteristics. Most important, HLAB27 associated arthritis may occur identical to the Reiter's syndrome with accompanying uretheritis and/or conjunctivitis, whereas in the B27 non-associated form this has not been clearly described. Likewise, only the B27 associated form belongs to the group of spondyloarthropathies.
\end{abstract}

(Ann Rheum Dis 1999;58:737-741)

Reactive arthritis was originally defined as a synovitis developing after a distant infection, and it was distinguished from postinfectious arthritis by absence of bacterial components in the joint tissue. ${ }^{12}$ The main effort of research in this field has been focused on the arthritides triggered by Chlamydia, Yersinia, Salmonella, Shigella, or Campylobacter, usually in HLA-B27 positive persons. However, several other infections may induce a similar reactive arthritis. These patients have only remained scattered, and a clear association of their disease to $\mathrm{B} 27$ is missing. Therefore, according to the triggering agent, the arthritides fulfilling the original definition of reactive arthritis could be considered to occur in two forms, one HLA-B27 associated and another HLA-B27 non-associated. Such a categorisation has already previously been

Turku Immunology Centre, Departments of Medical

Microbiology and

Medicine, Turku

University, Turku,

Finland

Correspondence: Dr P

Toivanen, Department of

Medical Microbiology, Turku

University, FIN-20520

Turku, Finland

Accepted for publication 26 August 1999

\section{Aetiology}

The majority, in some studies up to $90 \%$, of the patients contracting reactive arthritis after an infection with Chlamydia, Salmonella, Shigella or Yersinia are HLA-B27 positive. $^{78}$ The same applies to reactive arthritis following diarrhoea attributable to Campylobacter jejuni or to overgrowth of Clostridium difficile. Of the 19 B27 typed patients reported so far with reactive arthritis after Clostridium difficile associated diarrhoea $12(63 \%)$ were B27 positive..$^{9-13}$ It must be emphasised that it is not known whether the arthritis is attributable directly to Clostridium difficile or to changes of the intestinal flora; bacterial structures have not been demonstrated in the synovial tissue as is the case in arthritis triggered by Chlamydia, Salmonella, Shigella or Yersinia. ${ }^{14-21}$ It should also be noted that both the capacity for arthritis induction as well as B27 association may greatly vary even within a single bacterial species. Good examples are Yersiniae and Salmonellae. ${ }^{22}{ }^{23}$ In Salmonella outbreaks, a B27 frequency as low as $27 \%$ among the arthritis patients has been reported, which, however, is considerably more than in the general population. ${ }^{23}$

Among the pathogens in the genus Campylobacter, Campylobacter jejuni, fetus and lari are known to cause reactive arthritis. ${ }^{24}{ }^{25}$ Chlamydia trachomatis is a common cause of reactive arthritis, and cases attributable to Chlamydia pneumoniae ${ }^{26-30}$ and Chlamydia psittaci ${ }^{31}$ have also been reported. Among Clostridia, Clostridium difficile is the only one associated with reactive arthritis. Regarding salmonellas, no evidence exists to indicate that any of the species or serotypes that are human pathogens would be unable to induce reactive arthritis. ${ }^{32-34}$ Shigella flexneri has been thought to be the only one out of the four Shigella species capable of triggering reactive arthritis, but on the basis of two reports it seems that also the less virulent Shigella sonnei has this capacity. ${ }^{35}$ Within the genera of Yersiniae, both $Y$ enterocolitica and $Y$ pseudotuberculosis are causes of reactive arthritis, with arthritogenicity varying between and within different serotypes. ${ }^{122} \mathrm{~A}$ common nominator to all bacterial species discussed above is their capacity to trigger reactive arthritis predominantly in HLA-B27 positive persons.

Table 1 Bacterial genera with species triggering reactive arthritis

\begin{tabular}{ll}
\hline HLA-B27 association & \\
\hline established & not established \\
\hline Campylobacter & Borrelia \\
Chlamydia & Brucella \\
Clostridium & Haemophilus \\
Salmonella & Hafnia \\
Shigella & Leptospira \\
Yersinia & Mycobacterium \\
& Neisseria \\
& Staphylococcus \\
& Streptococcus \\
& Ureaplasma \\
& Vibrio \\
\hline
\end{tabular}


Table 2 Laboratory characteristics in reactive and bacterial arthritis

\begin{tabular}{lll}
\hline Characteristics & $\begin{array}{l}\text { Reactive } \\
\text { arthritis }\end{array}$ & $\begin{array}{l}\text { Bacterial } \\
\text { arthritis }\end{array}$ \\
\hline ESR mm 1st h (median) & 79 & 78 \\
CRP g/1 (median) & 129 & 125 \\
$\begin{array}{l}\text { Peripheral blood } \\
\text { Leucocytes } * 10^{\%} / 1 \text { (median) }\end{array}$ & 9.9 & 11.6 \\
$\begin{array}{l}\text { Synovial fluid }(\mathrm{knee}) \\
\quad \text { Leucocytes } 10^{9} / 1 \text { (median) }\end{array} \quad 19.0$ & 36.0 \\
$\quad$ Granulocytes; \% of leukocytes (median) & 85 & 89 \\
\hline
\end{tabular}

These findings are based on a study of 20 patients with B27 associated reactive arthritis and of 20 patients with culture positive bacterial arthritis. ${ }^{61}$ Reactive arthritis was caused by Yersinia (14 patients), Salmonella (4) or Chlamydia (2).

Bacteria that have been reported to cause reactive arthritis in an HLA-B27 independent fashion are listed in table 1. Among these, the infections caused by Borrelia burgdorferi represent a special entity because of the highly variable nature of Lyme disease. ${ }^{37-39}$ From the members of the other bacterial genera in table 1, Brucella abortus, Haemophilus influenzae, Hafnia alvei, Leptospirae, Mycobacteria, Neisseria gonorrhoeae, Neisseria meningitidis, Staphylococcus aureus, Streptococci, Ureaplasma urealyticum and Vibrio parahaemolyticus have been reported to trigger a disease fulfilling the original definition of reactive arthritis. ${ }^{3-6} 40-50$ For none of these has an association to HLA-B27 been observed. Likewise, several viral, fungal and parasitic infections are known to induce reactive arthritis without any clear association to HLA-B27. ${ }^{61-55}$ The same applies to reactive arthritis accompanying inflammatory bowel diseases, intestinal bypass, acne, cystic fibrosis, etc. ${ }^{66-60}$ A feature shared by bacteria triggering B27 non-associated reactive arthritis is their capacity to cause bacterial (septic) arthritis. In fact, the clinical and laboratory diagnosis between reactive and bacterial arthritis is often extremely difficult or even impossible, ${ }^{426162}$ (table 2), and knowledge of the bacteriological aetiology is of great help, ${ }^{63}$ and Jalava et al (unpublished data).

\section{Reactive or postinfectious?}

A question remains whether an HLA-B27 non-associated arthritis after a known or unidentified infection elsewhere in the body should be called postinfectious or reactive. More than 20 years ago postinfectious arthritis was defined as an inflammatory arthritis with non-culturable bacterial components present in the synovial tissue and reactive arthritis was regarded purely reactive, without any bacterial structures present at the site of synovial inflammation. ${ }^{12}$ Today it is known that nonviable bacterial structures are present in the synovial tissue of patients with B27 associated reactive arthritis ${ }^{14-21} 65$ as well as in other types of inflammatory arthritis. ${ }^{66}{ }^{67}$ Likewise, bacterial DNA occurs in the synovial cells in postinfectious arthritis attributable to Borrelia burgdorferi, ${ }^{68}$ Chlamydia trachomatis, ${ }^{69-72}$ Chlamydia pneumoniae ${ }^{73}$ or Neisseria gonorrhoeae, ${ }^{74}{ }^{75}$ with bacterial cultures being negative. In other words, it has become impossible to distinguish postinfectious and reactive arthritis by these criteria. You are left only with the definition of a sterile arthritis after a distant infection; this may or may not include demonstration of non-culturable bacterial components at the site of inflammation.

You could argue that the definition of reactive arthritis should be restricted to the most typical causes - that is, to Campylobacter, Chlamydia, Clostridium difficile, Salmonella, Shigella and Yersinia, for which the HLA-B27 association is known, and all others should be called postinfectious. However, the actual aetiology of a clinically typical reactive arthritis may remain unknown. Therefore, restriction of the term reactive arthritis only to these bacterial triggers seems not justified. It could be logical to divide reactive arthritis into two forms, one HLA-B27 associated and another HLA-B27 non-associated. You should note that association or non-association to HLAB27 is not $100 \%$, and that so called B27 associated bacterial species may induce even chronic reactive arthritis in B27 negative subjects, indicating that presence of HLA-B27 is not a prerequisite for chronicity. ${ }^{76}$ However, B27 most probably represents a risk factor for severity. ${ }^{77}$

In addition to causative agents and HLAB27, these two categories are distinguished by other characteristics (table 3). Most important, B27 associated arthritis may occur identical to the Reiter's syndrome with urethritis and/or conjunctivitis. In the B27 non-associated form

Table 3 Characteristics of the two forms of reactive arthritis

\begin{tabular}{lll}
\hline & Reactive arthritis & \\
\cline { 2 - 3 } Characteristics & HLA-B27 associated & HLA-B27 non-associated $t$ \\
\hline Triggers & Campylobacter, Chlamydia, Clostridium difficile, & A variety of other microbes \\
Cultivable microbes present in joint & Salmonella, Shigella, Yersinia & \\
Microbial structures demonstrated in joint & No & No \\
Differential diagnosis to bacterial arthritis & Yostly clear & So far only rarely \\
Oligo-or polyarthritis & Usually oligoarthritis, most commonly in & Often unclear \\
& Polyarthritis more common than in the B27 associated form; & other joints than knee affected as well \\
Reiter's syndrome & Occurs & Not usual, but found after genitourinary infections $\$ \\
Tendency for chronicity & Yes & Not clear \\
Evolution to ankylosing spondylitis & Possible & Not observed \\
Part of spondyloarthropathy group & Yes & No \\
Pathogenetic mechanisms & Similar to experimental antigen induced & Similar to experimental antigen induced arthritis \\
& arthritis; in addition, an HLA-B27 &
\end{tabular}

^Sixty to ninety per cent of patients with this form of reactive arthritis are HLA-B27 positive.

tIn patients with this form, HLA-B27 occurs in the same frequency as in the normal population.

§It is unclear if reactive arthritis developing after Ureaplasma and gonococcal infections is accompanied by other signs of Reiter's syndrome predominantly in HLAB27 positive patients. 

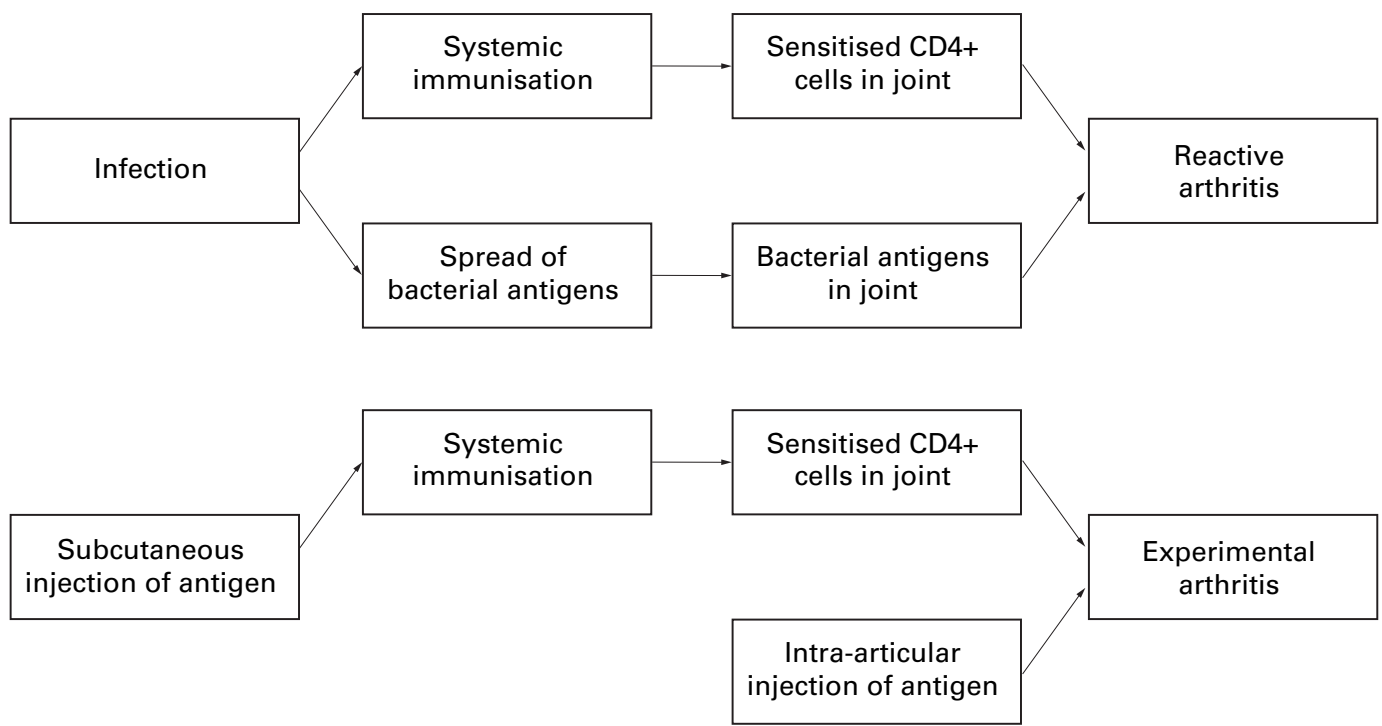

Figure 1 Pathogenesis of reactive arthritis, compared with that of experimental antigen induced arthritis. In the reactive arthritis, bacterial antigens end up in the joint tissue as a result of the infection. In the experimentally induced arthritis, the antigen (for example, BSA or non-viable bacterial antigen) is first given parenterally and two weeks later intra-articularly. In addition to the pathogenetic mechanism depicted here, an HLA-B27 dependent, so far unknown mechanism operates in the B27 associated form of reactive arthritis.

of reactive arthritis this has not been clearly described; it is unclear if reactive arthritis developing after Ureaplasma and gonococcal infections is accompanied by other signs of Reiter's syndrome predominantly in HLA-B27 positive patients. ${ }^{47}$

\section{Pathogenesis}

Are living bacteria always required for induction of reactive arthritis? The answer seems to be no, because the disease has been reported after vaccination with killed Salmonella bacteria $^{78}$ or with recombinant hepatitis B viral protein. ${ }^{79}$ In fact, human reactive arthritis greatly resembles experimental antigen induced arthritis, where an animal is first parenterally immunised and thereafter challenged intra-articularly with the same antigen (fig 1)..$^{81}$ Arthritis then develops as a $\mathrm{T}$ cell mediated reaction at the site of the challenge, with an immune complex mediated mechanism potentially also contributing. In the human reactive arthritis, the patient has a preceding infection during which they become naturally immunised against the aetiological agent. You must assume that during that process-that is, usually in one to three weeks-microbial antigens are transported to the synovial tissue. This may occur intracellularly within mononuclear or other phagocytosing cells, ${ }^{82}$ as immune complexes ${ }^{568-85}$ or even in the form of free antigen or proliferative bacterial bodies. ${ }^{66}{ }^{67} 70$ The consequence is a CD4+ cell mediated reaction, manifested as acute arthritis ${ }^{21}{ }^{86-91}$; immune complex mediated cytotoxicity may also participate, ${ }^{5683-85}$ similarly to experimental antigen induced arthritis. For development of a chronic antigen induced arthritis, a periodic or continuous supply of the antigen then is required. In the human patients this probably occurs from hidden reservoirs, which for instance for Yersinia seem to be the submucosal tissue. ${ }^{92} 93$

With this type of reasoning, the CD4+ cell mediated reaction, depending on immunologi- cal presensitisation must be a crucially contributing factor in the early pathogenesis of B27 associated and non-associated forms of reactive arthritis. In addition, when the triggering agent in an HLA-B27 positive person is Campylobacter, Chlamydia, Clostridium difficile, Salmonella, Shigella or Yersinia, an HLA-B27 associated mechanism is involved. It is possible that this mechanism, with a CD8+ cytotoxicity probably involved, ${ }^{94}{ }^{95}$ contributes to the chronicity and severity of arthritis in HLA-B27 positive persons. ${ }^{21} 779697$ You must note, however, that despite intensive research, the molecular basis of the B27 associated pathogenesis has so far remained a mystery.

Supported by the EVO of Turku University Central Hospital. We thank Drs Reijo Luukkainen, Timo Möttönen and Riitta Saario for critical reading of the manuscript.

1 Ahvonen P, Sievers K, Aho K. Arthritis associated with Yersinia enterocolitica infection. Acta Rheum Scand 1969;15:232-53.

2 Dumonde DC. Principal evidence associating rheumatic diseases with microbial infection. In: Dumonde DC, ed. Infection and immunology in the rheumatic diseases. Oxford Blackwell Scientific Publications, 1976:95-6.

3 Keat A. Reiter's syndrome and reactive arthritis in perspective. N Engl J Med 1983;309:1606-15.

4 Ford MJ, Hurst NP, Nuki G. Reactive arthritis-infectious agents and genetic susceptibility in the pathogenesis of sero-negative arthritis. Scott Med J 1983;28:34-41.

5 Lahesmaa-Rantala R, Toivanen A. Clinical spectrum of reactive arthritis. In: Toivanen $\mathrm{A}$, Toivanen $\mathrm{P}$, eds. Reactive arthritis. Boca Raton, FL: CRC Press, 1988:1-13.

6 Toivanen A, Toivanen P. Epidemiologic aspects, clinical features, and management of ankylosing spondylitis and reactures, and management of ankylosing spondylitis an

7 Brewerton DA, Caffrey M, Nicholls A, Walters D, Oates JK James DCO. Reiter's disease and HL-A 27. Lancet 1973;ii: James 8 .

8 Finch M, Rodey G, Lawrence D, Blake P. Epidemic Reiter's syndrome following an outbreak of shigellosis. Eur J Epidemiol 1986;2:26-30

9 Cope A, Anderson J, Wilkins E. Clostridium difficile toxininduced reactive arthritis in a patient with chronic Reiter's syndrome. Eur J Clin Microbiol Infect Dis 1992;11:40-3.

10 Putterman C, Rubinow A. Reactive arthritis associated with Clostridium difficile pseudomembranous colitis. Semin Arthritis Rheum 1993;22:420-6.

11 Sensini A, Marroni M, Bassotti G, Farinelli S, D'Alo F, Gentili AM, et al. Clostridium difficile-associated reactive arthritis in an HLA-B27 negative male. J Clin Gastroenarthritis in an HLA-B2

12 Boice JL. Reactive arthritis induced by Clostridium difficile. Western J Med 1994;160:171-2.

13 Keating RM, Vyas AS. Reactive arthritis following Clostridium difficile colitis. Western J Med 1995;162:61-3. 
14 Keat A, Thomas B, Dixey J, Osborn M, Sonnex C, TaylorRobinson D. Chlamydia trachomatis and reactive arthritis: the missing link. Lancet 1987;i:72-4.

15 Toivanen A, Lahesmaa-Rantala R, Ståhlberg TH, MerilahtiPalo R, Granfors K. Do bacterial antigens persist in reactive arthritis? Clin Exp Rheumatol 1987;5 (supp 1):25-7.

16 Schumacher HR Jr, Magge S, Cherian PV, Sleckman J, Rothfuss S, Clayburne G, et al. Light and electron microscopic studies on the synovial membrane in Reiter's syndrome. Immunocytochemical identification of chlamysyndrome. Immunocytochemical identification of chlamy-
dial antigen in patients with early disease. Arthritis Rheum dial antigen in patie

17 Granfors K, Jalkanen S, von Essen R, Lahesmaa-Rantala R, Isomäki $\mathrm{O}$, Pekkola-Heino $\mathrm{K}$, et al. Yersinia antigens in synovial-fluid cells from patients with reactive arthritis. N Engl J Med 1989;320:216-21.

18 Granfors K, Jalkanen S, Lindberg AA, Mäki-Ikola O, von Essen R, Lahesmaa-Rantala R, et al. Salmonella lipopolysaccharide in synovial cells from patients with reactive arthritis. Lancet 1990;335:685-8.

19 Keat ACS, Hughes R. Infectious agents in reactive arthritis. Curr Opin Rheumatol 1993;5:414-19.

20 Toivanen A, Toivanen P. Aetiopathogenesis of reactive arthritis. Rheumatol Europe 1995;24:5-8.

21 Burmester GR, Daser A, Kamradt T, Krause A, Mitchison NA, Sieper J, et al. Immunology of reactive arthritides. Annu Rev Immunol 1995;13:229-50.

22 Tertti R, Granfors K, Lehtonen O-P, Mertsola J, Mäkelä A-L, Välimäki I, et al. An outbreak of Yersinia pseudotuberculosis infection. J Infect Dis 1984;149:245-50.

23 Mattila L, Leirisalo-Repo M, Koskimies S, Granfors K, Siitonen A. Reactive arthritis following an outbreak of Salmonella infection in Finland. Br J Rheumatol 1994;33:113641 .

24 Peterson MC. Rheumatic manifestations of Campylobacter jejuni and C. fetus infections in adults. Scand J Rheumatol 1994;23:167-70

25 Goudswaard J, Sabbe L, te Winkel W. Reactive arthritis as a complication of Campylobacter lari enteritis. [Letter]. J Infection 1995;31:171-6.

26 Gran JT, Hjetland R, Andreassen AH. Pneumonia, myocarditis and reactive arthritis due to Chlamydia pneumoniae. Scand J Rheumatol 1993;22:43-4.

27 Braun J, Laitko S, Treharne J, Eggens U, Wu P, Distler A, et al. Chlamydia pneumoniae - a new causative agent of reactive arthritis and undifferentiated oligoarthritis. Ann Rheum Dis 1994;53:100-5.

28 Saario R, Toivanen A. Chlamydia pneumoniae as a cause of reactive arthritis. Br J Rheumatol 1994;33:1112.

29 Moling O, Pegoretti S, Rielli M, Rimenti G, Vedovelli C, Pristerá R, et al. Chlamydia pneumoniae - reactive arthritis Pristera R, et al. Chlamydia pneumoniae - reactive arthritis

30 Hannu T, Puolakkainen M, Leirisalo-Repo M. Chlamydia pneumoniae as a triggering infection in reactive arthritis. Rheumatology 1999;38:411-14.

31 Cooper SM, Ferris JA. Reactive arthritis and psittacosis. Am J Med 1986;81:555-7.

32 Ford DK. Reactive arthritis: a viewpoint rather than a review. Clin Rheum Dis 1986;12:389-401.

33 Mäki-Ikola O, Granfors K. Salmonella-triggered reactive arthritis. Scand J Rheumatol 1992;21:265-70.

34 Thomson GTD, Chiu B, De Rubeis D, Falk J, Inman RD. inmunoepidemiology of post-Salmonella reactive arthritis in a cohort

35 Young RH, McEven EG. Bacillary dysentery as the cause of Reiter's syndrome. JAMA 1947;134:1456-9.

36 Lauhio A, Lähdevirta J, Janes R, Kontiainen S, Repo H. Reactive arthritis associated with Shigella sonnei infection. Arthritis Rheum 1988;31:1190-3.

37 Steere AC, Schoen RT, Taylor E. The clinical evolution of Lyme arthritis. Ann Intern Med 1987;107:725-31.

38 Steere AC, Dwyer E, Winchester R. Association of chronic Lyme arthritis with HLA-DR4 and HLA-DR2 alleles. N Lyme arthritis with HLA-DR

39 Oksi J, Mertsola J, Reunanen M, Marjamäki M, Viljanen MK. Subacute multiple-site osteomyelitis caused by Borrelia burgdorferi. Clin Infect Dis 1994;19:891-6.

40 Alarcon GS, Bocanegra TS, Gotuzzo E, Hinostroza S, Carrillo C, Vasey FB, et al. Reactive arthritis associated with brucellosis: HLA studies. J Rheumatol 1981;8:621-5.

41 Winter RJD, Richardson A, Lehner MJ, Hoffbrand BI. Lung abscess and reactive arthritis: rare complications of leptospirosis. BMJ 1984;288:448-9.

42 Rush PJ, Shore A, Inman R, Gold R, Jadavji T, Laski B. Arthritis associated with Haemophilus influenzae meningitis: septic or reactive? J Pediatr 1986;109:412-15.

43 Maricic MJ, Alepa FP. Reactive arthritis after Mycobacterium avium-intracellulare infection: Poncet's disease revisited. Am J Med 1990;88:549-50

44 Newmark JJ, Hobbs WN, Wilson BE. Reactive arthritis associated with Hafnia alvei enteritis. Arthritis Rheum 1994;37:960.

45 Deighton C. $\beta$ Haemolytic streptococci and reactive arthritis in adults. Ann Rheum Dis 1993;52:475-82.

46 Tamura N, Kobayashi S, Hashimoto H, Hirose S-I. Reactive arthritis induced by Vibrio parahaemolyticus. J Rheumatol 1993;20:1062-3.

47 Horowitz S, Horowitz J, Taylor-Robinson D, Sukenik S, Apte RN, Bar-David J, et al. Ureaplasma urealyticum in Reiter's syndrome. J Rheumatol 1994;21:877-82.
48 Mader R, Zu'Bi A, Schonfeld S. Recurrent sterile arthritis following primary septic meningococcal arthritis. Clin Exp Rheumatol 1994;12:531-3.

49 Gutiérrez-Ureña S, Molina J, Molina JF, García CO, Cuéllar ML, Espinoza LR. Poststreptococcal reactive arthritis, clinical course, and outcome in 6 adult patients. J Rheumatol 1995;22:1710-13.

50 Siam ARM, Hammoudeh M. Staphylococcus aureus triggered reactive arthritis. Ann Rheum Dis 1995;54: $131-3$.

51 Burnstein SL, Liakos S. Parasitic rheumatism presenting as rheumatoid arthritis. J Rheumatol 1983;10:514-15.

52 Woo P, Panayi GS. Reactive arthritis due to infestation with Giardia lamblia. J Rheumatol 1984;11:719.

53 Kamel M, Safwat E, Eltayeb S. Bilharzial arthropathy. Immunological findings. Scand J Rheumatol 1989;18:31519.

54 Lee MG, Rawlins SC, Didier M, DeCeulaer K. Infective arthritis due to Blastocystis hominis. Ann Rheum Dis 1990;49:192-3.

55 Cron RQ, Sherry DD. Reiter's syndrome associated with cryptosporidial gastroenteritis. J Rheumatol 1995;22: $1962-3$.

56 Rose E, Espinoza LR, Osterland CK. Intestinal bypass arthritis: association with circulating immune complexes and HLA B27. J Rheumatol 1977;4:129-34.

57 Mielants H, Veys EM, Cuvelier C, De Vos M, Botelberghe L. HLA-B27 related arthritis and bowel inflammation. Part 2. Ileocolonoscopy and bowel histology in patients with HLA-B27 related arthritis. J Rheumatol 1985;12:294-8.

58 Moll JMH. Inflammatory bowel disease. Clin Rheum Dis 1985;11:87-111.

59 Leino R, Toivanen A. Arthritis associated with gastrointestinal disorders. In: Toivanen A, Toivanen P, eds. Reactive arthritis. Boca Raton, FL: CRC Press, 1988:77-86.

60 Roberts-Thomson PJ, Rischmueller M, Kwiatek RA, Soden M, Ahern MJ, Hill WR, et al. Rheumatic manifestations of infective endocarditis. Rheumatol Int 1992;12:61-3.

61 Kortekangas P, Aro HT, Tuominen J, Toivanen A. Synovia fluid leukocytosis in bacterial arthritis vs. reactive arthritis and rheumatoid arthritis in the adult knee. Scand J Rheumatol 1992;21:283-8.

62 Toivanen P, Toivanen A. Bacterial or reactive arthritis? Rheumatol Europe 1995;24 (suppl 2):253-5.

63 Wilbrink B, van der Heijden IM, Schouls LM, van Embden JDA, Hazes JMW, Breedveld FC, et al. Detection of bacterial DNA in joint samples from patients with undifferentiated arthritis and reactive arthritis, using polymerase chain reaction with universal 16S ribosomal RNA primers. Arthritis Rheum 1998;41:535-43.

64 Reference withdrawn.

65 Nikkari S, Rantakokko K, Ekman P, Möttönen T, LeirisaloRepo M, Virtala $M$, et al. Salmonella-triggered reactive arthritis. Use of polymerase chain reaction, immunocytochemical staining, and gas chromatography - mass spectrometry in the detection of bacterial components from synovial fluid. Arthritis Rheum 1999;42:84-9.

66 Lehtonen L, Kortekangas P, Oksman P, Eerola E, Aro H, Toivanen A. Synovial fluid muramic acid in acute inflammatory arthritis. Br J Rheumatol 1994;33:1127-30.

67 Li F, Nanagara R, Rothfuss S, Clayburne G, Sieck M, Yan Meng Z, et al. Demonstration of peptidoglycan in synovial fluid cells as a possible arthritogenic factor in psoriatic arthritis. [Abstract]. Arthritis Rheum 1994;37 (suppl) S204.

68 Nocton JJ, Dressler F, Rutledge BJ, Rys PN, Persing DH, Steere AC. Detection of Borrelia burgdorferi DNA by polymerase chain reaction in synovial fluid from patients with Lyme arthritis. N Engl J Med 1994;330:229-34.

69 Taylor-Robinson D, Gilroy CB, Thomas BJ, Keat AC Detection of Chlamydia trachomatis DNA in joints of reactive arthritis patients by polymerase chain reaction. Lancet 1992;340:81-2.

70 Nanagara R, Li F, Beutler A, Hudson A, Schumacher HR Jr. Alteration of Chlamydia trachomatis biologic behavior in synovial membranes. Suppression of surface antigen production in reactive arthritis and Reiter's syndrome. Arthritis Rheum 1995;38:1410-17.

71 Bas S, Griffais R, Kvien T, Glennås A, Melby K, Vischer TL. Amplification of plasmid and chromosome Chlamydia DNA in synovial fluid of patients with reactive arthritis and undifferentiated seronegative oligoarthropathies. Arthritis Rheum 1995;38:1005-13.

72 Gérard HC, Branigan PJ, Schumacher HR Jr, Hudson AP. Synovial Chlamydia trachomatis in patients with reactive Synovial Chlamydia trachomatis in patients with reactive arthritis/Reiter's syndrome are viable but show

73 Gérard HC, Branigan PJ, Schumacher HR, Hudson AP. Screening of synovial tissue from reactive arthritis (ReA) patients for the presence of Chlamydia pneumoniae. [Abstract]. Arthritis Rheum 1995;38 (suppl):S394.

74 Liebling MR, Arkfeld DG, Michelini GA, Nishio MJ, Eng $\mathrm{BJ}$, Jin $\mathrm{T}$, et al. Identification of Neisseria gonorrhoeae in synovial fluid using the polymerase chain reaction. Arthritis Rheum 1994;37:702-9.

75 Muralidhar B, Rumore PM, Steinman CR. Use of the polymerase chain reaction to study arthritis due to Neissepolymerase chain reaction to study arthritis due to
ria gonorrhoeae. Arthritis Rheum 1994;37:710-17.

76 Laivoranta S, Ilonen J, Tuokko J, Luukkainen R, Toivanen A. HLA frequencies in HLA-B27 negative patients with A. HLA frequencies in HLA-B27 negative patients with
reactive arthritis. Clin Exp Rheumatol 1995;13:637-40.

reactive arthritis. Clin Exp Rheumatol 1995;13:637-40.
77 Linssen A, Feltkamp TEW. B27 positive diseases versus B27 negative diseases. Ann Rheum Dis 1988;47:431-9. 
78 Calin A, Goulding N, Brewerton D. Reactive arthropathy following Salmonella vaccination. [Letter]. Arthritis Rheum 1987;30:1197.

79 Hassan W, Oldham R. Reiter's syndrome and reactive arthritis in health care workers after vaccination. BM 1994;309:94

80 Cooke TDV. Antigen-induced arthritis, polyarthritis, and tenosynovitis. In: Greenvald RA, Diamond HS, eds. Handbook of animal models for the rheumatic diseases. Vol. I. Boca Raton, FL: CRC Press, 1988:53-81.

81 Pettipher ER, Blake S. Antigen-induced arthritis. In: Henderson B, Edwards JCW, Pettipher ER, eds. Mechanisms and models in rheumatoid arthritis. London: Academic Press, 1995:457-70.

82 Salmi M, Andrew DP, Butcher EC, Jalkanen S. Dual binding capacity of mucosal immunoblasts to mucosal and synovial endothelium in humans: dissection of the molecular mechanisms. J Exp Med 1995;181:137-49.

83 Whittle HC, Abdullahi MT, Fakunle FA, Greenwood BM, Bryceson ADM, Parry EHO, et al. Allergic complication of meningococcal disease. I. Clinical aspects. BMJ 1973;2 $733-7$.

84 Goldenberg DL. "Postinfectious" arthritis. New look at an old concept with particular attention to disseminated gonococcal infection. Am J Med 1983;74:925-8.

85 Lahesmaa-Rantala R, Granfors K, Isomäki H, Toivanen A. Yersinia specific immune complexes in the synovial fluid of patients with Yersinia-triggered reactive arthritis. Ann patients with Yersinia-trigge
Rheum Dis 1987;46:510-14.

86 Gaston JSH, Life PF, Granfors K, Merilahti-Palo R, Bailey $\mathrm{L}$, Consalvey S, et al. Synovial T lymphocyte recognition of $\mathrm{L}$, Consalvey S, et al. Synovial T lymphocyte recognition of 1989;76:348-53.

87 Sieper J, Kingsley G, Palacios-Boix A, Pitzalis C, Treharne J, Hughes R, et al. Synovial T lymphocyte-specific immune response to Chlamydia trachomatis in Reiter's disease. Arthritis Rheum 1991;34:588-98.

88 Hassell AB, Pilling D, Reynolds D, Life PF, Bacon PA, Gaston JSH. MHC restriction of synovial fluid lymphocyte responses to the triggering organism in reactive arthritis Absence of a class I-restricted response. Clin Exp Immunol 1992;88:442-7.

89 Sieper J, Braun J, Wu P, Kingsley G. T cells are responsible for the enhanced synovial cellular immune response to triggering antigen in reactive arthritis. Clin Exp Immunol 1993;91:96-102.

90 Hermann E. T cells in reactive arthritis. APMIS 1993;101 177-86.

91 Lahesmaa R, Shanafelt M-C, Steinman L, Peltz G. Immunopathogenesis of human inflammatory arthritis: lessons from Lyme and reactive arthritis. J Infect Dis 1994;170:978-85.

92 de Koning J, Heesemann J, Hoogkamp-Korstanje JAA, Festen JJM, Houtman PM, van Oijen PLM. Yersinia in intestinal biopsy specimens from patients with seronegative spondyloarthropathy: correlation with specific serum IgA antibodies. J Infect Dis 1989;159:109-12.

93 Pelkonen P. Childhood systemic lupus erythematosus, vasculitis, and rheumatic fever and neonatal lupus. Curr Opin Rheumatol 1995;7:430-6.

94 Hermann E, Yu DTY, Meyer zum Büschenfelde K-H Fleischer B. HLA-B27-restricted CD8 T cells derived from synovial fluids of patients with reactive arthritis and ankylosing spondylitis. Lancet 1993;342:646-50.

95 Ackermann B, Staege MS, Reske-Kunz AB, Dienes H-P, Meyer zum Büschenfelde K-H, Märker-Hermann E. Enterobacteria-infected $\mathrm{T}$ cells as antigen-presenting cells for cytotoxic CD8 $\mathrm{T}$ cells: a contribution to the self-limitation of cellular immune reactions in reactive arthritis. J Infect Dis 1997;175:1121-7.

96 Leirisalo-Repo M, Suoranta H. Ten-year followup study of patients with Yersinia arthritis. Arthritis Rheum 1988;31: 533-7.

97 Feltkamp TEW. Factors involved in the pathogenesis of HLA-B27 associated arthritis. Scand J Rheumatol 1995;24 (suppl 101):213-17.

$\stackrel{3}{3}$ 